\title{
The Siberian Journey of Vasily Zhukovsky and Tsesarevich Alexander Nikolaevich in 1837: Two Images of the Russian East
}

\author{
Evgeniya E. Anisimova* \\ Siberian Federal University \\ 79 Svobodny, Krasnoyarsk, 660041, Russia
}

Received 26.12.2014, received in revised form 15.02.2015, accepted 22.05.2015

The article investigates regularities of psychological perception and image constructing of Siberia by V.A. Zhukovsky and tsesarevich (crown prince) Alexander Nikolaevich during their travel across Russia in 1837. On the materials of the travelers' letters, diaries and the 19th century periodicals, the author of the article shows the formation of two versions of Siberia's image. Alexander Nikolayevich's perception leant in many respects on cultural models familiar to him and provided mostly by the tradition of travel-writing ranging widely from the initiation archetypes to Russian practices of province revision. Zhukovsky, on the contrary, demonstrated the ability to separate the devices of literary travel from the circumstances of the real journey. The former he applied, when the voyage started, in his translation of the eastern story "Nala and Damaianti". It is shown in the article that the travel of the heir to throne was a marking event and it was included in the process of symbolic annexing of the isolated territory which was typical for imperial culture of the first half of the 19th century: the discourse of Siberia which was being created in the cultural centre was subjected in a larger degree to the idea of the integral imperial space. In the heir's notes about the travel the words of Siberians became the frame for this symbolic annexation. Seeing the future the czar for the first time on his land said: "hitherto Siberia was a peculiar land and now it became Russia".

Keywords: Zhukovsky, Alexander II, Siberia, travelogue, imagology, biography, reception.

The research is supported by the Russian Fund for the Humanities, grant № 14-14-24003.

DOI: 10.17516/1997-1370-2015-8-7-1373-1381

Research area: philology.

\section{Introduction}

\section{to the Subject Matter}

The aim of this work is to study "Siberian Chapters" of the famous traveling of V.A. Zhukovsky with his emperor student within the framework of the receptive prospects of the $19^{\text {th }}$ century culture. The materials for investigating were road diaries and letters of the poet and his fellow travelers, as well as official records of on the travel published in the contemporary periodicals. The study of these sources includes the reconstruction of the image of Siberia in the perception of the travelers. At the farewell audience Nicholas I declared to the

(C) Siberian Federal University. All rights reserved

* Corresponding author E-mail address: eva1393@mail.ru 
member entourage of the heir to the throne: "I want... Grand Duke to see things, as they are, not in a poetic way. Grand Duke should know Russia as it is" (Nikolai I: nastavleniia nasledniku, 1997, 56). Given that one of the companions of the Crown Prince was a known, national poet and his mentor, V.A. Zhukovsky, who was a latecomer that day and failed to hear the emperor's instructions, the remark inadvertently acquired additional overtones. The heir to the throne left a written testimony of visiting Siberia, which in the end revealed the poetic view of things, which the emperor was so feared. Zhukovsky himself, contrary to the expectations of his satellites and welcoming entourage inhabitants, showed gumption and a practical business approach to various issues - from production to the judicial system.

\section{Theoretical Grounds}

The scientific framework to investigate the traveling across Russia of Zhukovsky and the heir to the throne was set by Yu.M. Kurochkin, A.S. Ianushkevich and R.S.Wortman. With the involvement of a large array of pre-documents that are stored in the capital and in the local archives, Yu.M. Kurochkin described the Ural part of this trip in the light of regional studies (Kurochkin, 1988). A.S. Ianushkevich introduced the full text of the poetic road diaries into scientific circulation, accompanied by thorough commentary, researched the journey of Zhukovsky across Russia in imagelogical aspect and described patterns of its "political pedagogy" at the final stage of training of the heir to the throne (Ianushkevich 1997; Ianushkevich, 2004a; Ianushkevich, 2014). In his fundamental work devoted to the dynamics of "scenarios of power" in the Russian Empire, R.S. Wortman showed the place of the journey across Russia in 1837 in the ceremonial traditions of the Nicholas I era (Wortman, 2002, 473-482). In the opinion of the scholar, Nicholas I did away with the habit committed to the rising unrest and revolutions of the $18^{\text {th }}$ century, which took the children as potentials-governmental opponents of the current reigning ruler, and he offered a completely new dynastic power scenario. As part of the "family" scenario the figure of the heir to the throne and the process of his training, including the trip across Russia in 1837, acquired a special symbolic significance.

May 2, 1837 Tsesarevich Alexander accompanied by his mentor, V.A. Zhukovsky departed from Tsarskoye Selo on a trip across Russia. This trip was to complete the basic training of the heir to the throne. In the book "Russian culture in the mirror of travel" E.G. Miliugina and M.V. Stroganov identified four types of travel: academic, cognitive, representational, business plan review. They regarded the Tsesarevich trip as the third type, the special features of which are, according to the researchers, the following: "The third type of travel is executive voyage, having a dual-governmental purpose. On the one hand, the person traveling (most often it is a special imperial house or guiding face of the country) gets acquainted with the country and the people. $<\ldots>$ On the other hand, a person traveling on an executive voyage itself represents the reality of his existence to the country (Miliugina, Stroganov, 2013, 42).

\section{Siberian Travel Diary in 1837: Ideology and Mythological Poetics}

Naturally, the inclusion the far eastern edge of the empire, Siberia in the itinerary, significantly intensified mythological and poetical underpinnings of the travelogue, linking it to the poetics of "rites of passage", strengthened the emotional experience of dangers of the journey. The unprecedented trip across Russia was perceived in the key of the mythological "communion" of the prince to his 
future kingdom, it became a sort of initiation. The Russian aristocratic families in $19^{\text {th }}$ century had a tradition to end the period of training of a young men with a journey in which optionally he was to go without his parents (Liamina, Samover, 1999, 148). For most peers of Alexander Nikolayevich the destination of such a travel was Europe, but for himself the overseas voyage was supposed to be preceded by a large-scale tour across the country. Moreover, a visit to the European powers of the young Tsesarevich would inevitably mean the choice of the bride, who would finally secure the status of an adult heir to the throne.

According to observations of V.I. Tiupa, the symbolic roles of Siberian space in chronotopes of works of Russian literature were determined by motifs of the exile and prison and were closely related to the socio-cultural mythology of Siberia itself. "Siberia in the Russian cultural consciousness acquired characteristics and properties of the mythical land of the dead" (Tiupa, 2009, 254) - the researcher notes. In this context, the journey to Siberia for a young person was inevitably perceived in terms of the initiation necessary to transform the youngster into an adult man (Tiupa, 2009, 255). It should be noted that of all the members of the travel of 1837 the warmest reviews of Siberia were left by the Tsesarevich. It is clear that Alexander himself was aware that the trip to Siberia was the main test on his way, that he must pass with flying colors. New people that he met in the Urals in the letters of the Tsesarevich acquire characteristic poetic initiation monstrous features: "beast, not a man", "horrible monster", "vampires", etc. (Venchanie s Rossiei, 1999, 60, $62,68)$. The sense of danger of the undertaken unprecedented travel to Siberia is one of the main ideas associated with the trip in the documents both personal and official.

Another factor in the poetics and reception of Siberian travelogue by Alexander Nikolayevich and V.A. Zhukovsky was the aspect of ideological trip. R.S. Wortman, attempted to reconstruct the meanings of ideological journey in 1837 , pointed to the significance of this trip as part of a dynastic "scenario of power" of Nicholas I: "The journey of Alexander in Russia from April to December 1837, after his nineteenth birthday, was a dynastic scenario to the outskirts of the empire. Together with Zhukovsky and adjutant S.A. Iurevich, he went more than thirteen thousand miles. It was the longest journey of the king or an heir to the empire, which led him into those parts of the country, including Siberia, who had never been visited by any of the members of the imperial family" (Wortman, 2002, 473). In the scholar's opinion the "journey of Alexander showed the evolution of ceremonial applied to the coronation in 1826 - referring to the voice of the first publicly in support of the approval of the majestic St. Petersburg court of silence" (Wortman, 2002, 477). Thus, the general instruction of Nicholas I to his son was a wish to maintain a certain distance in relation to the provincial nobility, and, on the contrary, to show pleasant, friendly attention to the representatives of the democratic representatives of the merchant class and the peasantry. The future monarch was supposed to represent himself not only as the head of the nobility, but as a "people's king".

Siberian travelogue of 837 includes travel diaries and letters of members of the travel: first of all, the heir to the throne, Alexander Nikolayevich, his mentor, V.A. Zhukovsky and his personal secretary S.A. Iiurevich, as well as printed in "Northern Bee" official reports about the trip. Features of perception of the travel in 1837 in the documents were determined by the intersection of several cultures-governmental traditions. On the one hand, the understanding of the trip by its participants and observers was dictated by existing mythological\&poetical letter codes in a wide range of subjects from the ancient kind of initiation and traveling to the 
newest literary pretext - such as "Telemahida" by V.K. Trediakovsky or "Inspector" (Revisor) by N.V. Gogol. On the other hand, the journey of the Tsesarevich was associated with the solution of very specific ideological and geopolitical problems, but the real experience was often forced to question some of the myths and perceptions of Russia and Siberia.

In the perception of travelers and their families a travel across Russia of the $19^{\text {th }}$ century could prove to be both informative and entertaining, but also a dangerous enterprise. That is why in addition to officials and the Tsesarevich`s classmates, he was accompanied in his journey by the military doctor I.V. Enokhin and a special kitchen, which protected him against accidental meals. Nicholas I gave instructions that were supposed to protect the heir from a number of hazards on the road (Venchanie s Rossiei, 1999, 21-24). Thus, when signs of an indisposition at the Tsesarevich's schoolmate I.M. Wielhorsky were found, it was unanimously decided not to take him to Siberia. In a letter from Zhukovsky on May 18, 1837 to L.K. Wielhorsky, his mother he openly voiced "imaginary geography" ${ }^{1}$ of Siberia "I am sure that the trip will not hurt him (I.M. Wielhorsky.E.A.); he will make a nice part of it and will rest at a time when we will ride through the mountains and deserts" (Liamina, Samover, 1999, 155). In the lexicon of Zhukovsky the words "desert" and "Siberia" were closely interlinked. So, in 1830 he completed a utopian project of amnesty of Decembrists within Siberia borders. According to this text, whether participants in the event in 1825 given the freedom in Siberia, it had the good influence not only on them alone. Highly educated Decembrists that were zealous for their work for the good of the state were supposed to convert Siberian "desert" (Dubrovin, 1902, 77).

However, despite the concerns that made the author of travel notes apply the monotonous cliché to "Siberian text" and even identify their trip to Siberia with a caravan passing through a desert (Dorozhnye pis'ma SA Iur'evicha, 1887, 452), Emperor Nicholas I formed a travel initiative, regarded it as a necessary event and he had a good reason for that. The first direction of the voyage of the heir to the throne was chosen precisely Siberia, and its east point Tobolsk. Unlike traveling incognito the public ceremony of travel of royals usually assumed a symbolic joining of the territory. Thus, the famous kingdom voyage across the territory of Russia of Catherine II to the south of the empire was organically fit into her "Greek project". But in the first half of the $29^{\text {th }}$ century Russia was facing other geopolitical objectives. According to the observations of historians, "Already in the first half of the $19^{\text {th }}$ century in the government-governmental circles appeared doubts about reliability of the Siberians, feeling that Siberia could follow the example of the North American colonies. There were questions about the so-called political exiles, especially polish people, fugitive peasants from the central provinces, as well as old believers, who spread the idea that "Russia was separate, and Siberia was separate" (Sibir "v sostave Rossiiskoi imperii ). The Tsesarevich journey of 1837 was chronologically between the two large revisions of Siberia by M.M. Speranskiy in the late 1820 s and N.N. Annenkov in the beginning of the 1850s. Officially the journey of the heir to the throne was not a revision, and the Emperor specifically warned his son from public expression of non-pleasure during military and civilian parades. However, the letters from Tsesarevich to Nicholas I show how thoroughly the future monarch recorded the pain points in the management of the regions of the empire. The literary code in this dialogue of the father and the son was chosen at home earlier at the personal order of the Emperor the comedy 
of N.V. Gogol "The Government Inspector" (Revisor) (Venchanie s Rossiei, 1999, 30, 130).

After the Tsesarevich`s entering in Siberia poetics of his letters to his father visibly started to change. Previously they mainly focused their attention on military parades, but here audit observations of Siberia clearly acquired an adventurous element having integral, behindthe-scenes down and out. The main topics that affect Tsesarevich in his Siberian letters were wealth, separatists and robbers. And all that, in the opinion of Alexander Nikolayevich, was worthy of wonder. On the one hand, the image formed in the letters of the Tsesarevich included real facts and observations of the traveler and in part confirmed awaited concerns about the isolation of that region, on the other hand, it met the mythopoetic criteria of the image of "another kingdom". Siberia appeared to be a space of exceptional features, wealth and at the same time a world that had inhabitants with a special lifestyle that did not fit into the traditional notion of the norm. This image of Siberia was attached to the other key motive of Siberian travelogue of 1837. The repetitive motive of the letters to the emperor framing all Siberian journey was the heir's expressive perception of the Ural foreigners, who had seemingly incompatible features: Asian appearance and Western European clothing (Venchanie s Rossiei, 1999, 60). The Siberian diary of the heir is full of exotic details and it captures the situation of a cultural frontier in the region.

In his letter dated June 3, 1837 the Tsesarevich gave a detailed portrait of the social life and household of Siberians, who, on the one hand, were simple and modest, and on the other hand, to a large extent explains the ambivalence of the image of Siberians of the first half of the $19^{\text {th }}$ century. (Venchanie s Rossiei, 1999, 53-54). In his further perceptions of the journey, the heir to the throne of Russia mainly focused his attention on his intercessions in favor of the exiled Decembrists. However, compared to the other mentioned topics the subject of "the involved in the case of the 14 $4^{\text {th }}$ (as Alexander called Decembrists), set out in a report to Nicholas I for June 6, 1837 looks quite succinctly.

\section{The Image of Siberia in Zhukovsky's Travel Diary}

The "Siberian travelogue" of Zhukovsky was significantly different from the road letters of the Tsesarevich. The poet used translation of the Indian novel "Nal' i Damaianti" as a literary "convoy" for his journey, and creative thinking of the artist was embodied in a variety of his drawings. Yet the road records of the mentor turned out to be much less literary than the Tsesarevich`s reports to Nicholas I. If we use the wording of the Emperor, we can say that Zhukovsky's diary describes "things as they are". "The Siberian text" of the poet was reflected in his detailed diary for this period and many road letters, in particular, epistolary "reports" about the trip to Empress Alexandra Feodorovna. Nicholas I ordered that each member of the journey kept a diary, and the Tsesarevich kept his own diary, however, he recorded dates mostly, distances, and names of the visited places. More detailed descriptions of the journey circumstances and his perceptions were reflected in his letters to his father. Zhukovsky, on the contrary, would make much more diary records. It was largely dictated by his continuous practice of keeping a diary (Ianushkevich, 2004, 397). However, due to the constant journey haste these records were often quite laconic.

While traveling in the direction of Siberia, May 16, 1837, Zhukovsky began translating fragments of the first chapter of the Indian novel "Nal 'i Damaianti" in the German version of F. Ruckert. The appeal to the Indian theme along with the movement eastwards was symptomatic. 
A notable fact is that during a subsequent trip of the heir to Europe in 1838-1839 he did not continue his work on the Indian story (Zhiliakova, 2010, 385). Comparisons Siberia to India were quite common among the contemporaries of Zhukovsky and later researchers (Pis'ma MM Speranskogo, 1868, 1685; Lieven, 2007, 362). About robbers, old believers and non-Russians who were of interest for the Tsesarevich the poet in his travel diary mentions only briefly. The center of his attention was devoted to issues of industrial production (Kurochkin, 1988, 19) and the names of people he met along the way. His many letters were accompanied by short records and characteristics which were described in more detail. Zhukovsky`s philanthropic travel stories of 1837 can be attributed to this typical feature of his diary poetics, most of which became known from the episode of his assistance for the Decembrists.

Zhukovsky`s behavioral and diary strategies that were implemented during his trip in 1837 turned out to be very similar to many future "Siberian travel documentaries" of the $19^{\text {th }}$ century. Alexander was the first representative of the ruling dynasty to visit Siberia and Zhukovsky opened a series of voluntary travels of writers to Russia's east. The travel records of the poet largely anticipated "ethnographic" Siberian travelogues of I.A. Goncharov and A.P. Chekhov, manifesting a departure from the purely literary style. According to T. Grob, "this form of description can appear only in the own space of the narrator in Russia. <... Is not exotic, even "paradise" awakens the interest of the narrator, but the space of the "other", which is actually a model of his own world" (Grob, 2010, 56).

\section{Conclusion}

The Tsesarevich journey was included in the process of assigning a symbolic separate territory, which was a characteristic of the imperial culture of the first half of $19^{\text {th }}$ century: the discourse established in the center of Siberia begins to focus more on the idea of integrality of the imperial space. In the notes on the visit of the heir the words of Siberians became a symbol of this joining. The Siberians saw the future emperor for the first time on their land. These words were first in the private correspondence of travel, and then appeared on the pages of the official press. June 3, 1837, when he was in Tobolsk, Tsesarevich wrote to his father: "I do not know how to thank you, dear Father, for what you sent me here because my stay here and the residents gave me emotional joy. They say that hitherto Siberia was a special country and now we made it Russia" (Venchanie s Rossiei, 1999, 53). Two weeks later, in the "Northern Bee" for June 18, 1837 it was published: "In Siberia, His Highness was particularly pleased to see grain-producing soil, abundant pastures and extraordinary wealth of all the gifts of nature, many of which have hitherto not been touched because of the poor population. Residents of this remote region are delighted with joyful emotions and gratitude for the visit of the heir and they exclaim everywhere: "Hitherto our land was Siberia; and now it became Russia" (Vnutrennie izvestiia, 1837, 537).

\footnotetext{
On that see Bassin, 2004.
}

\section{References}

1. Venchanie s Rossiei (1999). Perepiska velikogo kniazia Aleksandra Nikolaevicha s imperatorom Nikolaem I [Wedding with Russia (1999). Correspondence Grand Duke Alexander Nikolaevich with Emperor Nicholai I]. 1837. Publ. by L.G. Zakharova and L.I. Tiutiunnik, Moscow: Moscow State University Press, 184 p. 
2. Vnutrennie izvestiia (1837) Severnaia pchela. № 135. 19 iunia. [Internal News (1837) Northern Bee. № 135. 19 June]. Pp 537-538.

3. Grob, T. (2010) Pisatel' "V begakh”: puteshestvie Antona Chekhova na ostrov Sakhalin i na okrainu literatury. Beglye vzgliady: Novoe prochtenie russkikh travelogov pervoi treti 20 veka: Sb. st. M.: Novoe literaturnoe obozrenie [Writer "On the run": Anton Chekhov's journey to Sakhalin Island and on the outskirts of the literature. A quick look: The new reading of the Russian travelers of the first third of the 20 century: Sat. Art. Moscow: New Literary Review]. Pp. 37-57.

4. Dorozhnye pis'ma S.A. Iur'evicha (1887) vo vremia puteshestviia po Rossii Naslednika Tsesarevicha Aleksandra Nikolaevicha v 1837 godu. Russkii arkhiv. Vyp. 4.[Travellers letters of S.A. Yurevich (1887) during the trip across Russia of the heir Tsarevich Alexander Nikolaevich in 1837. Russian archive. Vol. 4]. pp 441-468.

5. Dubrovin, N.F. (1902) Vasilii Andreevich Zhukovskii i ego otnoshenie k dekabristam. Russkaia starina. [Vasily Zhukovsky and its relation to Decembrists. Russian Antiquity]. T. 110. Vol. 4, Pp 45119.

6. Zhiliakova E.M. (2010) "Nal' i Damaianti”. Kommentarii. Zhukovskii V.A. Poln. sobr. soch. i pisem ["Nal' and Damaianti”. Comments. V.A. Zhukovsky Full. cit. Op. and letters]: 20vol. 5 vol.. Moscow, 2010. Pp. 379-399.

7. Kurochkin, Yu.M. (1988) Ural'skii voiazh poeta. Cheliabinsk: Iuzhno-Ural'skoe knizh-noe $i z d$-vo [Urals voyage of the poet. Chelyabinsk: South Ural publ]. $143 \mathrm{p}$.

8. Lieven, D. (2007) Rossiiskaia imperiia i ee vragi s 16 veka do nashikh dnei [the Russian Empire and its enemies from the $16^{\text {th }}$ century to the present day]. Moscow: Publishing House "Europe". $688 \mathrm{p}$.

9. Liamina, E.E., Samover, N.V. (1999) “Bednyi Zhozef”: Zhizn' i smert' Iosifa Vi-el'gorskogo: Opyt biografii cheloveka 1830-kh godov. ["Poor Joseph": The Life and Death of Joseph Wielhorsky: Experiences in writing the biography of a man of the 1830s]. Moscow: Languages of Russian culture. $560 \mathrm{p}$.

10. Miliugina, E.G., Stroganov, M.V. (2013) Russkaia kul'tura v zerkale puteshestvii [Russian culture in the mirror of travels]. Tver: Tver. state. Univ. $176 \mathrm{p}$.

11. Nikanorova, E.K. (1995) Motiv "neuznannogo imperatora" v istoriko-belletristicheskikh proizvedeniiakh kontsa $18-19 \mathrm{vv}$. Rol' traditsii v literaturnoi zhizni epokhi. Siuzhety i motivy. [The Motif of the "unrecognized Emperor" in historical and fictional works of the late 18 - 19 centuries. The role of tradition in the literature-life of the era]. Themes and motifs. Novosibirsk: SB RAS. Pp. 39-52.

12. Nikolai I: nastavleniia nasledniku (1997). Materialy k puteshestviiu tsesarevicha Aleksandra Nikolayevicha po Rossii i Evrope v 1837-1839 godakh. Publ., primech., st. N. Samover. Nashe Nasledie. [Nicholai I: Instructions for the heir (1997). Materials to travel of the Crown Prince Alexander II across Russia and Europe in the years 1837-1839. Our Heritage. № 39-40. Pp. 50-57].

13. Pis'ma M.M. Speranskogo (1868) k ego docheri iz Sibiri. Russkii arkhiv. [Letters of M.M. Speranskii (1868) to his daughter from Siberia. Russian archive]. Vol. 11. STB. 1681-1811.

14. Sibir'v sostave Rossiiskoi imperii (2007). Moscow: Novoe literaturnoe obozrenie [Siberia in the Russian Empire (2007). Moscow: New Literary Review]. 368p. 
15. Tiupa, V.I. (2009) Sibirskii intertekst russkoi literatury. Analiz khudozhestvennogo teksta. [Siberian Intertext of Russian Literature. Tiupa V.I. Analysis of Literary Text]. Moscow: Publishing Center “Academy". Pp/ 254-264.

16. Wortman, R.S. (2002) Stsenarii vlasti. Mify i tseremonii russkoi monarkhii [The scenarios of power. Myths and ceremony of the Russian monarchy]. Moscow: OGI. 1. T. 608 p.

17. Ianushkevich, A.S. (1997) Neopublikovannye stranitsy "Dnevnikov" V.A. Zhukovskogo. Novoye literaturnoe obozrenie. [Unpublished pages of "Diaries" of V.A. Zhukovsky. New Literary Review]. № 28. Pp. 159-179.

18. Ianushkevich, A.S. (2004) Dnevniki V.A. Zhukovskogo kak literaturnyi pamiatnik [Diaries of V.A. Zhukovsky as a literary monument]. Full. cit. Op. and letters: 20 t. T. 13. Moscow: Languages of Slavic culture. Pp. 397-419.

19. Ianushkevich, A.S. (2004a) Puteshestvie s velikim kniazem [Travel with the Grand Duke]. V.A. Zhukovsky Full. cit. Op. and letters: 20 t. T. 14. . Moscow: Languages of Slavic culture. Pp/ 434-463.

20. Ianushkevich, A.S. (2014) Puteshestvie V.A. Zhukovskogo s velikim kniazem po Rossii v 1837 godu kak imagologicheski tekst [Travel of V.A. Zhukovsky with the Grand Duke across Russia in 1837 as an imagelogical text]. Gorno-Altaisk: The Dialogue of Cultures: poetics of the local text Pp. 14-23.

21. Bassin, M. (2004) Imperial Visions. Nationalist Imagination and Geographical Expansion in the Russian Far East, 1840-1865. Cambridge: Cambridge University Press. 331 p. 


\title{
Путешествие В.А. Жуковского
}

\section{с наследником престола Александром Николаевичем \\ в Сибирь в 1837 г.: два образа русского востока}

\author{
Е.Е. Анисимова \\ Сибирский федеральный университет \\ Россия, 660014, Красноярск, пр. Свободный, 79
}

В статье исследуются закономерности психологического восприятия и образного конструирования Сибири В.А. Жуковским и иесаревичем Александром Николаевичем во время их путешествия по России в 1837 г. На материале писем, дневников путешественников и периодики XIX в. показано формирование двух версий имагологического образа Сибири. Восприятие будущего Александра II во многом опиралось на известные ему культурные модели подобных путешествий в широком диапазоне - от архетипов инициации до русских практик ревизии провинции. Жуковский, напротив, продемонстрировал умение отделять литературный контекст путешествия, которым стал для поэта начатый им при выезде перевод восточной повести «Наль и Дамаянти», от обстоятельств реальной поездки. В статье показано, что путешествие наследника престола было событием знаковым и включалось в характерный для имперской культуры первой половины ХІХ в. прочесс символического присвоения обособленной территории: создающийся в иентре дискурс Сибири начинал в большей степени ориентироваться на идею интегральности имперского пространства. В записках о поездке наследника символом этого присоединения стали слова сибиряков, впервые увидевших на своей земле будущего императора: «Доселе Сибирь была особенная страна и теперь сделалась Россиею».

Ключевые слова: Жуковский, Александр II, Сибирь, травелог, имагология, биография, реиепџия.

Исследование проходило в рамках гранта № 14-14-24003 Российского научного гуманитарного фонда.

Научная спещиальность: 10.00.00 - филологические науки. 